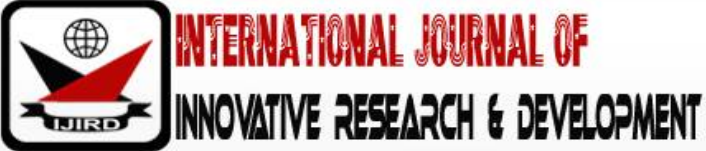

ISSN 2278 - 0211 (Online)

\section{Effectiveness of Free Senior High School Double Track Policy System and Its Impact on Student Performance in the Nkoranza North and South District, Ghana}

Dongber Anselm Yirper
Teacher, Department of Ghana Education Service,
Second Cycle Institution (Senior High School), Ghana
Romanus Ziem
Research Assistant, Department of KTCSR,
University for Development Studies, Ghana

\begin{abstract}
:
Ghana educational system has over the years gone through various reforms through the introduction of varied policies and programs aimed at bringing quality and affordable education to the doorstep of its citizens. Recently introduced at the secondary level is the free senior high school policy which seeks to improve both enrollment and performance of students. The increase in enrollment numbers resulted in the adoption of the double track system to deal with the problem of inadequate infrastructure that most of these second cycle institutions are grabbling with. This study, therefore, documents the impact of the free senior high school policy in its current practicein Ghana; precisely, in the Nkoranza North and South Districts. Through both structured and semi-structured interviews, it was observed that the policy has resulted in increased enrollment of students, reduced class sizes, improved contact hours between students and teachers and more holidays for enough rest. However, the double track system was observed to besaddled with numerous challenges. They included inadequate stakeholder consultation, inadequate infrastructure, untimely disbursement of funds, poor meals and increased financial burden on parents. It is against this backdrop that the study recommends that government should established sustainable funding sources, undertake massive infrastructure expansion, broader stakeholder consultation on the policy sustainability and political commitment in policy implementation.
\end{abstract}

Keywords: Policy, free senior high school, double track system

\section{Introduction}

Globally, the role that education plays in developing individuals, communities, societies and nations cannot simply be overemphasized. Apart from being the bedrock for developing the human resource base, its role in bridging social and income inequalities remains unmatched. According to McWilliam and Kwamena-Poh (1978, p.10) 'the main purpose of education, be it formal or informal, is to support the individual to assimilate into society and subsidise to societal and national development'. It is thus not surprising that education in contemporary discourse is seen as a fundamental human right of which every persons of school going age is entitled to hence the need for great time investment to help citizens to integrate into the world of work and contributing massively to national development.

Ali et al, (2009) posed that education is important for the development of individuals as well as societies, and that also lead us to a successful and productive future. According to Mensah, (2019) education is an instrument that fuel and speed up the rapid growth of the socio-economic, political, technological, scientific, and cultural environment globally. As a social institution, education is designed to prepare the youth to take up leadership roles in society through the provision of knowledge, skills and attitudes. The power of education, through science, technology and innovation, is being harnessed by countries across the world to create wealth because it leads to improvement in the living conditions of people. Mensah, (2019) added that the emergence of globalization is increasing the wealth and influence of those who have acquired the competencies and innovative in their thinking. However very little natural resources like gold, diamond, timber and agricultural lands, have been transformed into wealthy nations through sustained progress in education.

In realization of the above potentials of education, Ghana has since time immoral attempted to make use of formal education to produce the human resource needed to develop raw materials of the country. Lot of efforts in the area of policies and programs have been committed to in ensuring that education is accessible, affordable and of quality irrespective of social stratifications and classes. Mention of some the policies and programs can be made of the free compulsory universal education (FCUBE) which is a constitutional provision in the country, northern scholarship program, school feeding program, community day schools' concept, among others. Characteristics of all these policies to increase enrollment numbers without comprising on quality education. All these educational interventions have varied 
drawbacks. For instance, the FCUBE which was implemented to provide good quality education for all children of schoolgoing age in Ghana specially at the basic level experienced a lot of challenges including poor performance, inadequate access to education services, weak management capacity, unsatisfactory financing arrangement and primary education was not reformed to enhance Junior High School (JHS) education (Acedo, 2009).

Not as a stopgap but rather a sustainable approach to solving the above constraints that have bridled the educational sector, the Government of Ghana in September 2017 introduced the Free Senior High School (Free SHS) policy. The underlying tenants of the Free SHSpolicy was to increase school enrollment, improve quality and performance and affordable education at the secondary level. Taking note of the 2017/2018 academic year, enrolment into first year of Senior High School was 424,092 students, representing an increase of approximately 63\% in first-year enrolment over that of 2014/2015 academic year 275,609 students (Ministry of Education, 2015). This means that enrolment derived has increase and that accessibility aspect of implementing the policy have been achieved.

Currently the Free Senior High School Double Track Policy is about to enter its third year come September 2020 and analysis shows as at the beginning of the policy implementation total student population in secondary schools across the country will hit over one million indicating the highest enrollment since independence. According to Mensah(2019), the first year of the policy implemented witness enrolment of over 400,000 students in the second cycle institutions. The following year about 500,000 students were enrolled into second cycle institutions. This therefore indicates that enrolment derive will hit over one million students into second cycle schools.

The enrollment numbers at the secondary level in the Nkoranza North and South Districts is no different. A school in the district before the Free SHS was having a total population of about 500 students but this has increased to almost 1000 students (ibid).With increment in enrollment, the system becomes pregnant with infrastructure deficits, high rate of teenage pregnancies as a result of long and frequent semester breaks. Besides, teaching and learning activities have been affected because of the inadequacy of teaching manuals and textbooks for the core subjects and the government inability to provide elective textbooks under the policy.

It is against the above backdrop that the study seeks to investigate the impact of the policy on student performance and the associated prospects and challenges of the double track system as the main implementation approach of the policy.

\section{Literature Review}

\subsection{Theoretical Concept of Policy}

The policy process as indicated by Sutton (1999) depicts the process as direct, coherent or a top-down strategy with two different phases; formulation and implementation of policy. Howard, (2005) as cited by Bridgeman and Davis, (2003) that the importance of adaptations of policy as they present a cycle is key for a standard understanding public policy decision making. Howard (2005 p.3) indicated that policy cycle is an impractical, nonmature model for decision making. Everetts, (2003 p.66) added that politician and administrators have limited options to associate since their prominence is more on formal actions, they ignore the complex, value-laden nature entrenched in a policy cycle (Howard, 2005). Inkoom, (2012) indicated that policy development is dynamic and involves multiple actors and negotiations and the inflexible form of the national and scientific model does not consent room for this. Howard (2005) added that policy cycle needs to capture how politicians cooperate with officials to take-out good analytical work. Everett, (2003 p.66) indicated as cited by Davis, et.al, (1993) policy cycle is an administrative and official instrument for efficiently setting process in place once the different decisions have been made. Everett, (2003) added that it is imperative that tendencies are predicted so as to regulate if issues are likely to change. A Rural Health Research Panel, (2007 p.7) of the view that decision makers are provided with timely objective and expert analysis of the implication of policy appropriately. Everett (2003); Hess, (1999) and Davis et.al, (1993) stand on the position that some tenders for reform charge better than others; and Hess, (1999 p. 495) indicated that interviews with policymakers reveal that they are more highly selective in their deliberation of signal possible for new reforms than with carefully regulated calculation of verified routine. Clear objectives are set if a policy is to be success. Rodrigue, et.al, (2009) indicated that objectives must be consistent and flexible enough as condition advance. Policy objectives formulation as cited by Rodrgue et.al, (2009 p. 295) involves; identify the present state and condition, indicate what the goals are, identify walls to achieving the goals, identify what is needed from the other agencies and private sectors, determine how success will be judged and measured and identifies what steps are required to achieve success. Hess, (1999) and Everett, (2003) post that the choice of problem and objectives based on what is prompt and feasible than Rodrigu, et.al, (2009) that objective and problem need to be clearly defined. It is obvious that the problem, objectives and even targeted group needed to be clearly identified.

\subsection{Policy Implementation}

According to Bybee (2003 p.23) implementation involves altering policies, programs and practices to be reliable with standards. Implementation simply mean putting the policy document into action. For effective implementation and sustainability of educational policy Fredua-Kwarteng (2008 p. 433) indicated that it is flexibility to implement the policy at the community school level with the support of stakeholders, and curriculum being made to suit local needs and compulsory teacher upgrading into local philosophy and pedagogy. Fredua-Kwarteng (2008 p. 434) added that undertaking implementation challenges, bottom-up approach needs to incorporate with policy implemented through encouragement from local community participation. 


\subsection{Policy Evaluation and Monitoring}

Bybee, (2003 p.23) indicated that monitoring and feedback within the various machineries of the system as vital since this results in an ongoing evaluation of policies, programs and practices. According to Todd and Wolpin, (2006) policy makers attach great importance to both ex -ante and ex- post evaluations of the policy process. Rodrigue et.al, (2009 p.295) agreed with Todd and Wolpin (2006 p. 1) that ex- ante evaluation save the possibility of high cost of implementing programs that are later found to be ineffective. Ex -ante assessment provide indication on what range of effect to expect after the program is implemented. Rodrigue et.al, (2009 p.297) believe that policy objectives, the results and beneficiaries should be evaluated precise at the commencement when policy is formulated. Bybee, (2003) added that effective reform of policy and program are achieved and standard enhanced if evaluation is built into all stages of the policy process.

\subsection{Ghana Educational Reforms after Independence}

There are various educational policies introduced by every successive governments after independence with the expedition of providing Ghanaians with an upright and effective educational system. These reforms or policies includes; The Accelerated Development Plan of 1951 and Education Act of 1961, Reforms of the National Liberation Council, The New Structure and Content of Education of 1974, The 1987 education reforms, FCUBE programme of 1995, New Educational Reform of 2007, The Free Senior High Schools-Double track policy system 2017.

\subsection{The Accelerated Development Plan of 1951 and Education Act of 1961}

The 1951 accelerated development plan for basic education aimed to provide a six-years basic primary course for all children of school going age. The plan made basic education structure starting from primary one (1) to six (6) years and middle school education of four (4) years (both terminal and continuing) (Akyeampong, et.al.,2007. P.5). Sackey, (2008) position that continuing students could move into technical education, teacher training colleges, secondary schooling of five (6) years and a sixth form education of two (2) years for entry into tertiary education. A large number of untrained pupil teachers became the order of the day, and the trained teachers in primary and middle schools dropped from 52 to 28\% (Godwyll, 2003).

Akyeampong, et.al, (2007 p.5) indicated that the introduction of the 1961 education Act and government commitment to a fee free, compulsory primary and middle school education. Agbenyega (2007) added that acknowledging the contribution of the 1961 Act to the policy theme of educational access as stated in the Basic Education Division of GES Report (2004). Adamu-Issah, et.al., (2007) confirm the tuition free with free textbooks of the policy. Government of Ghana, (2004) indicated that without sufficient trained teacher's quick extension exposed cooperating the quality of education. Foster, (1965. P. 190) as indicated in Akyeampong, et.al., (2007, P.5) 'the educational plan criticisms had led the British administration to carefully allocate educational facilities disregarded more notable outcomes of educational growth. The system leads to a lowering of academic standards within the primary and middle schools and immediate teacher training schemes enable the system recover a rapid rate at the preliminary time enrolments was past. Akyeampong et.al, (2000) indicated that untrained teachers at the primary level school went up to $65 \%$ of the total teaching staff. At the secondary level saw emigrant teachers. The education system was however completely academic and pupils were leaving middle school after obtaining general education. Adamu-Issah et.al, (2007) indicated that early policies to increase access to education were that expansion and quality improvements needed to work together to produce equal benefits. According to Pobih, et.al., (1999); Foster, (1965), stakeholders look at quality education and expanded access to education and conducted assessment on the accelerated education expansion plans and focus more on the provision of quality education.

\subsection{Reforms of the National Liberation Council}

The National Liberation Council overthrew Dr. Kwame Nkrumah's government on 24 February 1966, which was spearheaded by Major A.A. Afrifa and General E.K. Kotoka, and to recover the crucial economic situation in the country, few major decisions were taken in the educational sector. Two committees, the Kwapong Education Review Committee (headed by Prof. Alex Kwapong of the university of Ghana and the Mills-Odoi Commission were appointed to review the educational system On March 7, 1966. The 1966 education reform committee recommended that elementary education be extended to eight years (Government of Ghana, 2004). Akyeampong et.al (2007 p.6) indicated that the candidates were selected for a further four years secondary education and those not selected more for two years of continuation classes with an emphasis on pre-vocational education. In the late 1960s to early 1970s primary education was seen many as research for entry to either secondary education or middle schools for early employment. Middle school leavers could attend technical and vocational schools and four-years post-primary teacher training colleges (Martin,1976). Adams \&Anum (2005) indicated unbalanced access to secondary education became an issue in the early 1970s. the continuation school concept was criticized as encouraging inferior education for the populace and secondary schools are preserve of choice Ghanaian children (Akyeampong et.al.2007. p.6)

\subsection{The New Structure and Content of Education of 1974}

The National Redemption Council (NRC) led by Col. Ignatius Kutu Acheampong succeeded the Busia government, and in 1972, a committee was set up to prepare proposals on the new structure and content of education for the discussion of the public. The committee (Dzobo Education Review Committee, headed by Professor N.K. Dzobo of the faculty of education, University of Cape Coast) came out with a new structure and content of education. Ministry of information and National Orientation (2007) as cited by Tagoe (2011) that education reforms in 1974, introduced the concept of 13 years of pre- tertiary education; 6 years primary school, three years for Junior Secondary School (JSS) and three Senior Secondary School (SSS). The Ghana Teaching Service (GTS) was renamed Ghana Education Service (GES) in 
1974 to implement various policies or reforms. The system introduced nursery and kindergarten type of education that gear toward children of 18 months and 24 months, Basic School cover a period of 9 years for free and compulsory, Secondary School for 4 years, vocational courses, pre-university level education, and engaged students' activities. The basic education certificate examination (BECE) determined a student next level to senior secondary school. Tagoe, (2011) is of the view that BECE examination which determines a candidate next level have replaced the common entrance examination in 1974. Senior Secondary School was for duration of four years. Pre-technical and pre-vocational subjects were considered by the committee. Akyeampong et.al (2007) indicated that an attempt was made for the junior secondary school curriculum comprehensive and that cater for all talents and provide students with practical skills. The 1974 educational reforms were implemented in pilot form at a time when the Ghanaian economy had declined. Akyeampong et.al, (2007 p.8) indicated that the index of monthly earnings fell from US\$315 to US\$ 62 and capita income was 30\% below the 1970 level. The period face shortage of teachers, textbooks and instructional materials throughout the country's schools (Inkoom, 2012). The policies gear toward education were not implemented by Gen Acheampong's Regime. However, in 1986 only 118 Junior Secondary Schools were established as experimental schools. (George et.al 1976)

\subsection{The 1987 Education Reforms}

The 1987 education Reforms aimed to improve access to basic education and implement the 1974 reforms nationwide. It also emphasised the need to include quality, efficiency and equity within the education sector (Ghana Education Service, 2004). Akyeampong et.al (2007) indicated that the system create room for all products of primary school to have access to higher level of general academic training. They added that practical skills training in technical and vocational subjects were provided for all children of school going age. Also, to prepare majority of children whose formal education terminated after Junior Secondary school for the world of work. the curriculum research and development division of GES (2007) post that curriculum combined general academic studies and practical skills training activities as indicated in ministry of education report (2000). Akyeampong, (2002) indicated that well-equipped Junior Secondary School workshops intended for skills training in pre-vocational and pre-technical education failed to work as planned due to an inadequate supply of well-trained technical and vocation instructors.

\subsection{FCUBE Programme of 1995}

The FCUBE stand for Free, Compulsory Universal Basic Education. It is a comprehensive programme designed to provide good quality education for all children of school-going age in Ghana at Basic Education Levels-Kindergarten, Primary and Junior High School (JHS). It is one of the Ministry of educations policies on education. The FCUBE programme is not quite different from the on-going educational reform programmes at the basic level. It is rather to strengthen those programmes-to address the main constraints that the reforms face at the basic levels-primary and J.H.S. Agbenyega, (2007) indicated that the provision and support for education has been granted by the 1992 constitution of Ghana as a basic human right for all Ghanaian. Tagoe, (2011) indicated that the free compulsory universal basic education (FCUBE) reform 1995-2005 was introduced to overcome weaknesses in the 1987 reform. Tagoe, (2011) cited with Sackery, (2008) that the policy is to improve teaching processes and leaving outcomes, build capacity to manage the basic education system and improve access to basic education considering girls and the poor in the society. The ministry of information and National Orientation (2007) indicated that pre-tertiary education in 1996 included 2 years optional kindergarten and six years of primary education, 3 years at Junior Secondary School and 3 years at Senior Secondary School (SSS) and that has reduced pre-tertiary education system from 17 to 12 years. After completion of Junior Secondary School, several options are available for students like technical/Vocational schools or training colleges, polytechnics or universities. According to Akyeampong et.al, (2007, P 10). The 1995 FCUBE reform faced similar challenges of the previous reform in terms of how to sustain early gains in enrolment and universalize basic education for all. Bame, (19991) added that the challenges were linked with over-emphasis on material inputs rather than how teachers' attitude and behavours in existing education system to handle unfamiliar pedagogical issues embedded in the revised curriculum.

\subsection{Educational Reforms of 2007}

The New Patriotic Party (N.P.P.) won power in the 2000 general elections in Ghana. After two years, the government inaugurated a committee chaired by Professor Josephus Anamuah Mensah, Vice Chancellor of University of Education, Winneba to review the education system. The key principles underlying the introduction of this reform includes: development of human resource for industrial growth, maintain the traditional indigenous knowledge or creativity and also improved science and technology. The John Agyekum Kuffour led administration introduced a new education system which did not only to review the content of the system but also extended the duration of Senior High School from three (3) years to four (4) years. It is vital to note that, the first year in the SHS was dedicated to study 'core subjects' such as English Language, Mathematics, Integrated Science, Information Communication Technology (ICT) and Social Studies. The Anamuah Mensah report show no different from that of the 1987 reforms. The only difference was the inclusion of two (2) years Kindergarten into the Universal Basic Education hence making it eleven (11) years of Universal Basic Education. The Universal Basic Education was structured into two (2) years of Kindergarten, six (6) years of Primary Education, three (3) years of Junior High School (JHS) (Akyeampong, 2007).

According to Adamu-Issah et.al., (2007) the 2007 reforms include the medium of instruction in Kindergarten and lower primary to be in Ghanaian Language. Also, emphasis was placed on Literacy, Numeracy and Creative Arts at the basic level and the change from three (3) years of Senior Secondary School (SSS) to four (4) years of Senior High School (SHS). The committee's ideology to this change of years in SHS is to ensure that teachers should be able to finish the syllabus and also give students adequate time to prepare for the West African Secondary School Certificate Examination 
(WASSCE). It is worth to note that, the 2008 general elections saw the New Democratic Congress (NDC) reversing the decision made by the NPP with respect to four (4) years in Senior High School back to three (3) years. Irrespective of the anticipated change in educational policies with change political administration; every successive governments in Ghana placed much faith in education as a major instrument for rapid social and economic development. However, this prioritize education led to several changes of educational reform.

\subsection{Free Senior High School Policy}

The Free Senior High School (FreeSHS) policy is a policy that was introduced in September 2017 under administration of NPP. The policy creates an enabling environment for every Ghanaian child who has completed Junior High School gain admission into the second cycle institution while reducing the rate of street children, child labour, school dropouts and others in the country. In fact, the Free Senior High School Policy was introduced to make secondary school accessible, quality and providing equality for all Ghanaian children of school going age. The system resulted to so many Ghanaian children gained admission into the second cycle institutions across Ghana hence the introduction of the Double Track System. The double track system policy was introduced by the government of Ghana into the Free Senior High School System projected it for the next five to seven years. According to Ghanaian times on the $20^{\text {th }}$ June, 2019 the system was introduced by the government of Ghana on the 11 $1^{\text {th }}$ September, 2018 starting with green track students enrolled for the 2018/2019 academic year, and that has generated a divergent view of absorbing more students into the Senior High School (SHS) and increase enrolment while reducing the class size. Ghanaian times $20^{\text {th }}$ June, 2019 added that the system was to deal with the large number of placed candidates who will hitherto not have had the chance to access Free Senior High School as a result of lack of classroom space. The double track system is into two sessions, thus the Green Track which is the first batch of students to be at school for a semester and the Gold track followed during the Green Track students' vacation on the academic calendar. The system moves the termly system to semester base in the second cycle institutions across Ghana. The system brought about change in instructional hours, instead of six hours it has move to eight hours per day. The system has about 41 days' vacation period for each track and that guarantee some sort of worries among parents.

\section{Methodology}

The research design, sampling techniques and sample size, research instrument, Data collection procedure, Data analysis procedure and Data presentation are the methodologies used to gather data for the study.

\subsection{Research Design}

Before a researcher could conduct a study, he or she needs to consider several choices relating to the study. According to Palys, (1992) the first decision to consider is to decide on how to carry out an investigation base on choices between qualitative and quantitative methodologies. Derbile, (2003) of the view that there has been opposition along the lines of these methods in the field of research into any discipline be it in the natural or social sciences. This sometimes creates a problem of which approach to consider in carrying out the study. The option between these two research methods is important because they point out diverse fundamental epistemologies and research philosophies. This study adopted the mixed method approach of the research design. The mixed method approach base on qualitative data which was first of all collected and quantitative data was also later on collected to help explain much on qualitative data results (Creswell et.al, 2009). The mixed method was used because it deals with an all-inclusive and in-depth research questions than a single research method (Creswell et.al, 2006). The researcher therefore used qualitative and quantitative research approaches base on the purpose of the study as well as the relevance mixed methods attached to a research document which obviously gives clear picture and narration of the realities that exist regarding to the topic. The interview methods and survey were used to gather data in the field. The researcher conducted the interview to gather data as a reference point and further conduct a survey to collect data in connection with issues relating to the topic.

\subsection{Sampling Technique}

The researchers used purposive sampling procedure to select Two (2) Headmasters and Four (4) Assistance Heads. Simple random sampling procedure was also used to select fourteen (14) students and thirty (30) teachers from both Districts. Purposive sampling as indicated by Creswell, (2009) is an intentional way of selecting individuals' respondents who have in-depth knowledge of the phenomenon. Cohen, et al (2008) also posed that simple random sampling enables all participants have equal chances of being selected and this idea was attached to the teachers and students of the study.

\subsection{Sample Size}

According to Webster, (1985). Sample is a finite part of statistical population whose properties are studied to gain relevant information about a whole. With regard to social research which has to deal with people, it can be a set of respondents selected from a whole population for a purpose of the study. this is a challenge most researchers do face when it comes to sample size selection however the quality and accuracy of the research is influence by unsuitable, insufficient sample size. The total sample size was made up of fifty (50) public senior high school teachers, assistance heads, students and headmasters, in the Nkoranza North and South in the Bono East region (newly created region) of Ghana. 


\subsection{Research Instrument}

The study adopted structured interview and semi structured interview as key instrument for the study. These instruments helped the researcher gathered accurate and relevant data in the field and to avoid biases.

\subsection{Data Collection Procedure}

The researcher granted semi structured interviews to the headmasters and assistance heads of the selected second cycle institutions. This was done to collect an in-depth information in connection with the effectiveness of the Free Senior High School double track policy system and its impact on student performance. The teachers as well as student were granted structured interviews on the impact of Free Senior High School double track policy system in the Nkoranza North and South Districts.

\subsection{Data Analysis and Presentation Procedure}

The researcher gathered both qualitative and quantitative data. The qualitative data obtained from interviews were analyzed using statistical package for social science (SPSS) software. Results of the analysis were presented in tables and figures for easy comparison of the various responses.

\section{Results and Discussions}

\subsection{Socio-Demographic Characteristics of Respondents}

The sample size for the study was 50 respondents out of which $62 \%$ s were male and $38 \%$ females. $6 \%, 32 \%, 38 \%$, $22 \%$ and $2 \%$ of these respondents where within the age brackets $10-20,21-30$ and $31-40,51$ and above respectively. They comprised of both students accounting for $28 \%$, first degree and diplomat holders $64 \%$ and post graduates $8 \%$ who are staff of the Ghana Education Service. With regards to their marital status, $42 \%$ were married whiles $58 \%$ were single or not married.Majority of the respondents were Christian $88 \%$ and Islam $12 \%$. These figures are presented on table 1 below;

\begin{tabular}{|c|c|c|}
\hline & Characteristics & Percentage \\
\hline \multirow[t]{2}{*}{ Sex } & Male & 62 \\
\hline & Female & 38 \\
\hline \multirow[t]{5}{*}{ Age } & $10-20$ & 6 \\
\hline & $21-30$ & 32 \\
\hline & $31-40$ & 38 \\
\hline & $41-50$ & 22 \\
\hline & $51+$ & 2 \\
\hline \multirow{3}{*}{$\begin{array}{l}\text { Educational } \\
\text { Status }\end{array}$} & Tertiary (University/Polytechnic & 64 \\
\hline & Post Graduates & 8 \\
\hline & Students & 28 \\
\hline \multirow{2}{*}{$\begin{array}{l}\text { Marital } \\
\text { Status }\end{array}$} & Married & 42 \\
\hline & Single & 58 \\
\hline \multirow{2}{*}{$\begin{array}{l}\text { Religious } \\
\text { Status }\end{array}$} & Islam & 12 \\
\hline & Christianity & 88 \\
\hline
\end{tabular}

Table 1: Socio-demographic Characteristics of Respondents Source: Field Survey, 2020

Male dominance in Ghana education sector is quite ancient and caused by socio-cultural practices. In sometraditional societies, prominence has not been given to female educationdespite the general acknowledgement that when you educate a woman, you have educated a nation. Tradition and customs have defined and limited the roles of women to the kitchen and not classroom. And this has affected female dominance in the other formal sectors because they do not have the requisite skills to be engaged.

\subsection{Progress of Policy Implementation}

Every policy has to be implemented through action. The objectives of the policy are converted into action. The implementation stage involved a lot of activities whereby key actors play various roles to achieved the said objectives. The issues of making education free for every Ghanaian child of school going age saw a greater number of students having access to the secondary schools in Ghana and that led to great number of students enrolled into secondary schools in the Nkoranza North and South District hence called for an intervention of solving accommodation issues by introducing the double track system. 


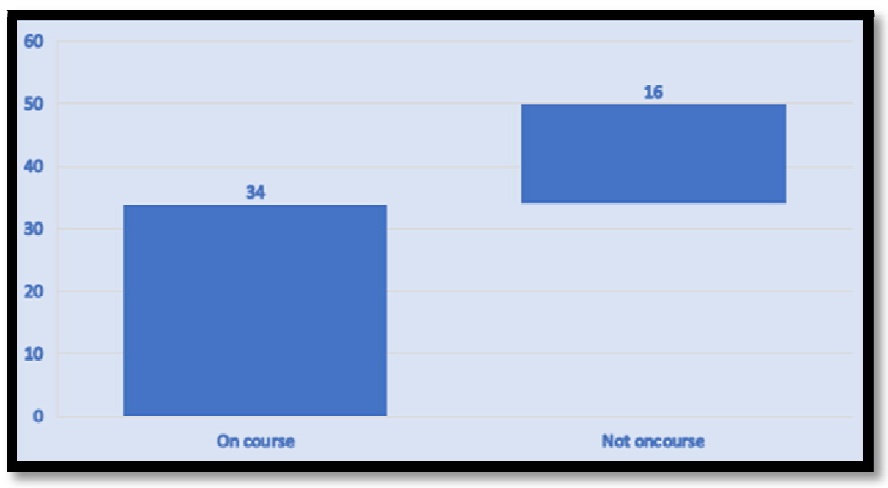

Figure 1: Implementation Progress

Source: Field Survey, 2020

Figure 1 above indicates that about 35 respondents out of the 50 confirmed that the policy implemented is in progress whereas 15 respondents disagree with the policy implementation progress in public secondary schools. Majority confirm that students' fees, utility bills are paid for every child, and government again supply the needs of every child including uniforms, books, mattress, beds etc. The study revealed that most students have been enrolled into senior high school with their numbers resulting to accommodation and classrooms problems hence the introduction of the double track system and that led to the building up of more structures to accommodate every child in the school in a near future. The policy hassled to the practice of sending students home for owning school fees being halted.

\subsection{Prospects of The Free Senior High School Policy}

Figure 1 below highlights the prospects of the policy in the study area to include increase in students' enrollment $42 \%$, less pressure on teachers $36 \%$, recruitment of new teachers $14 \%$, reduction in the financial burden of parents $2 \%$ and expansion in infrastructure $6 \%$.

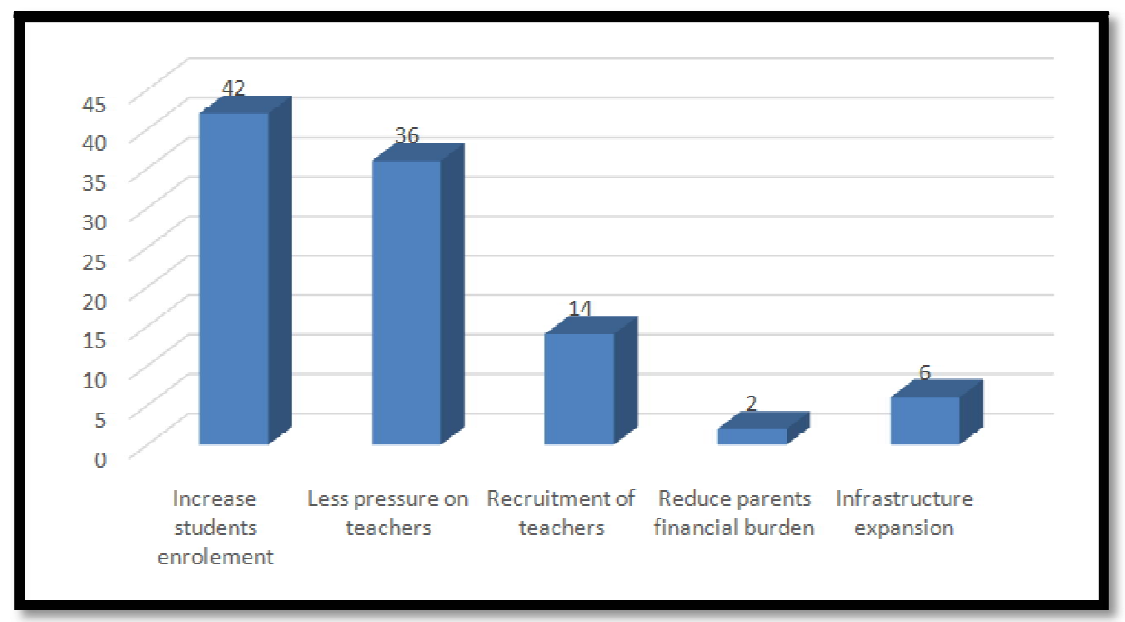

Figure 2: Prospects of the Policy

Source: Field Survey, 2020

It is evident from the above that the policy objective of increasing school enrollment at the secondary level is on course in the study area. This can be attributed to the non-payment of tuition and boarding fees which hitherto prevented a lot of students especially those from poor homes from continuing their secondary education. Conscious efforts from parents and well-wishers are being made to encourage children attend and take their pre-tertiary education serious since it comes with virtually no cost.

Another intriguing findings of the study was that there is now less pressure on teachers. As it stands now, the annual average number of teaching days are 225 and hours 1,134, with 112 days of vacation (MoE, 2020). With the double track system in place to run the policy, students are divided into two batches and each batch has its own set of teachers. In effect, teachers have smaller classes size to monitor and supervise which has the tendency for improved learning. The rotation of these batches for academic activities and vacation also ensure that teachers have enough time to rest since all work and no play makes Jake a dull boy.

The increment in enrollment figures triggered the need to recruit more teachers in the schools to effectively handle the various courses. To this end, graduates from the universities who were without jobs before the implementation of the policy were offered employment opportunities to teach and also earn income for a decent living.

It was also discovered that the policy has brought some relief to parents and guardians in educating their wards. Before the introduction of the policy, parents used to complain of high cost of boarding and tuition fees and this has accounted for the reason why some children could not continue with their secondary school after completion the free compulsory basic education. With government intervening in this area and other aspects, parents are somewhat relieved 
of that burden since there are no fees to worry about. Monies and other scarce resources that would have been used in paying fees are now channeled into other productive ventures for enhanced livelihood.

It is also imperative to mention that the policy also led to expansion in education infrastructure. With increasing enrolment numbers, government had to invest in constructing new dormitories, dinning halls, class rooms, teachers' bungalows, furniture for students and teachers, and other teaching and learning materials in order to accommodate the students. In effect, the schools have been given a face-lift which was almost a routine call on the government by most of the headteachers and parent teachers associations.

\subsection{Effectiveness of the Double Track System}

The effectiveness of the double track system was assed based on the objectives of the system which are to create room for the increased enrolment figures, reduce class size, increased contact hours and increase the number of holidays. It was discovered from the survey that the introduction of the double track system ensured education for all which accounted for $50 \%$ of the respondents interviewed. $10 \%$ and $20 \%$ of the respondents said the tracking system has increase student-teacher contact hours and reduction in class size respectively with $30 \%$ admitting that the number of holidays has increased. Figure 3 below is a representation of the responses obtained;

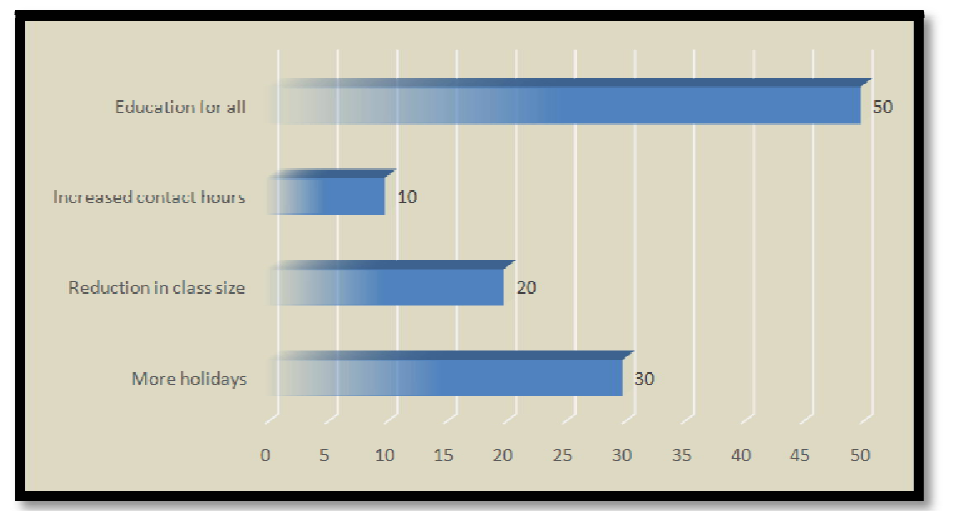

Figure 3: Effectiveness of the Double Track System Source: Field Survey, 2020

The implementation of the policy resulted in general increment in enrollment numbers at the secondary level. According to Partey (2018), in September 2017 enrolment increased by 33.2\%. Since the introduction of the policy, enrollment figures in the Nkoranza north and south district have witnessed an average of $15 \%$ increment intake in each academic year as illustrated on the graph below;

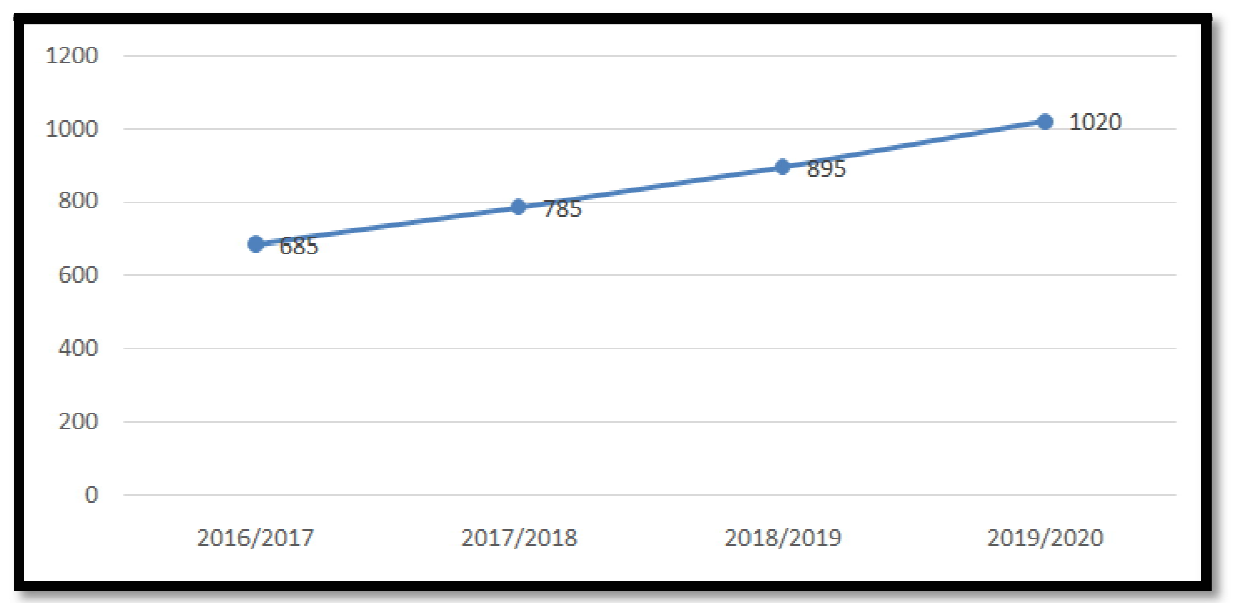

Figure 4: Enrollment Trend from 2016 to 2020 Source: Field Survey, 2020

The surge in enrollment figures without corresponding expansion in infrastructure would have meant that most these students were to be left out of school because of the absence of facilities to accommodate them. But with the double track in place, yearly intake is divided into two batches and rotated alternatively for their academic activities.

The division of students into batches would definitely have an effect on the number of students in a class and contact hours and $20 \%$ and $10 \%$ of the respondent interviewed attest to this respectively. The study discovered that whereas the core courses have about an average of 50 students in a class, the elective courses have about 20 students in a class. Such small class sizes make it easier for effective monitoring and supervision of academic works and also lessen the burden on teachers in carryout their duties. It also creates the opportunity for effective interaction and learning among students. Maintaining a balanced class size and increased contact hours is very essential for improved academic performance and quality education. 
It was also observed that the number of holidays that students go on in the double track system have increased. $20 \%$ of the respondents interviewed noted that students spend much time at home than in schools. The maximum number of annual holidays of current system is 16 weeks compared to the 12 weeks of the single-track system. Also, the number of teaching days have reduced from 180 days as in the old system to 162 days in the new system (MOE, 2018). So, clearly students now have more resting days and less days for their academic work.

\subsection{Students Performance Before and After the Double Track System}

Figure 5 below depicts students' performance before and after the implementation of the double track system. Under the single-track system, about $11 \%$ of students were able to score $80 \%$ mark and above compared to $2 \%$ of students getting the same grade under the double track. The situation was not different for the number of students who could obtained $70 \%$ mark and above as $24 \%$ was recorded for the single track and $9 \%$ for the double track. However, under the double track, the percentage of students obtaining marks between $50 \%-60 \%$ was higher than before the policy was implemented as $12 \%-20 \%$ of students could obtained it compared to about $8 \%-4 \%$ under the single track. Unfortunately, the number of students scoring lower marks under the double outweighed that of the single track as $1 \%$ and $3 \%$ of students obtained $40 \%$ and below mark for the single and the double track respectively.

Based on the above figures, it would not be meretricious to conclude that the double track is only good at producing average students. The number of very good and excellent students produced under it are far less than those of the single track that it sorts to replace. Moreover, the percentage of failed students are also higher under the double track than in the single track. If this trend should continue, then, the objective of quality education for all could be threaten.

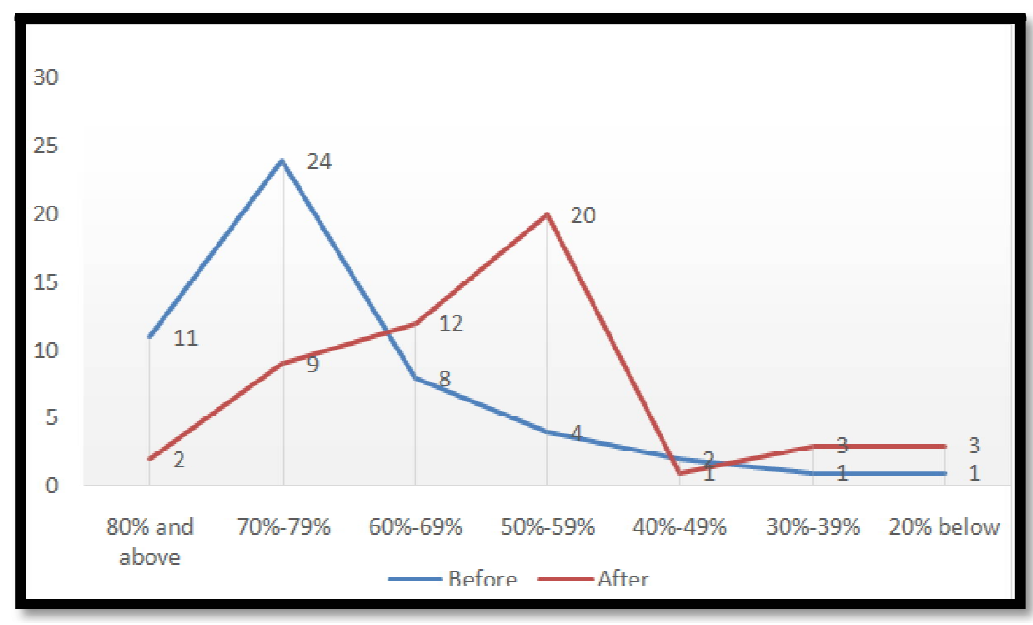

Figure 5: Performance Before and After the Double Track Source: Field Survey, 2020

\subsection{Challenges of the Double Track System}

The implementations of any new policies or programs, more often, are characterized with some challenges especially when there is no broader consultation of stakeholders and actors in that sector. And same can be said with the introduction of the free senior high school double track system which was characterized with some bottlenecks and constraints. The respondents interviewed bemoaned that the policy in its current form is grabbling with inadequate infrastructure, social vices, poor quality of meals, reduced contact hours between teachers and students, late disbursement of funds and also lack of motivation for teachers as shown on figure 5 below;

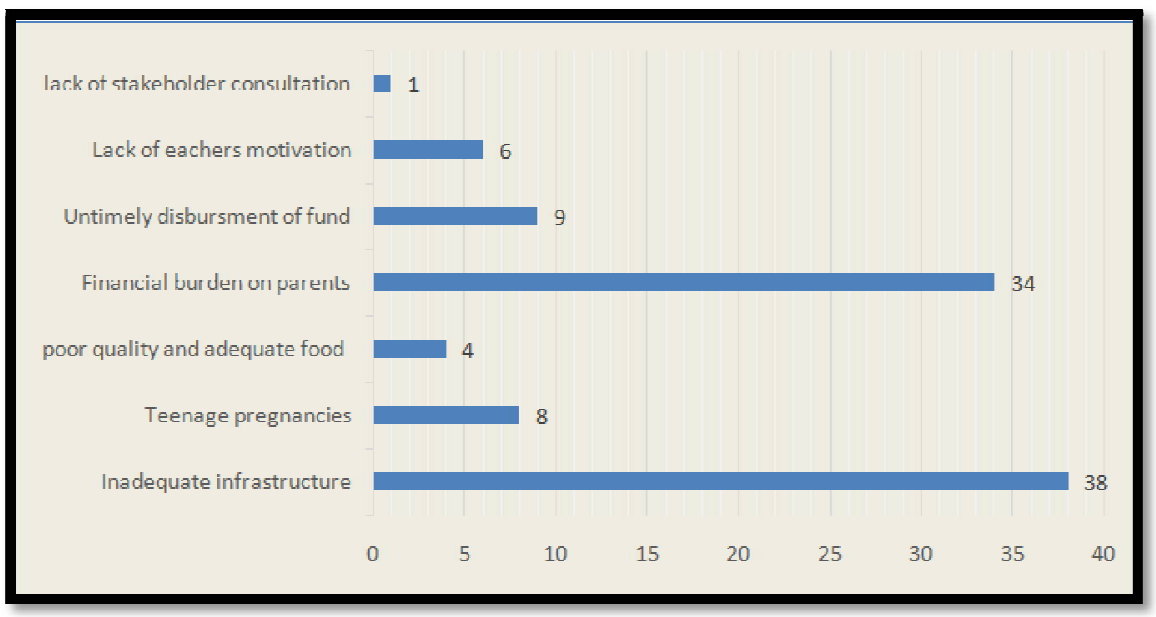

Figure 6: Challenges of the Double Track System

Source: Field Survey, 2020 
The success or otherwise of any policy largely depends on the level of engagement of the various stakeholders in that sector. Policies are meant to impact positively on individuals and societies thus the need for a broader consultation on the cost and benefits and its long run sustainability. The study, revealed that actors in the educational sector in the Nkoranza north and south districts were somehow not consulted on the formulation and implementation of the double track system. In fact, some of the respondents' content that it was a campaign promise that the government rushed over to implement without engaging the appropriate authorities. As such there was no proper analysis of cost and benefit, sources of funding, administrative management, and social impact assessment was done.

The exponential increment in enrollment figures exerted pressure on infrastructure which cannot be expanded overnight. This compelled most schools to convert dining and entertainment halls to dormitories and classrooms just to accommodate the students. Although the double track system was introduced to tackle this challenge nationally, the schools in the Nkoranza north and south district which prior to the implementation of the policy had serious infrastructure deficit were seriously affected as indicated by 38 of the respondents interviewed. It was to avert the infrastructure constrains that under the progressive free education policy, the concept of community day schools was introduced which saw the construction of community day schools across the country to absorb the 'excess students'. But this was abandoned or not given the needed attention as a result of change in government.

According $8 \%$ of the respondents interacted with, social vices especially teenage pregnancies among students became an issue in the study area since the shift system came into force. The two accounting factors for this was the infrastructure deficit and the long vacation periods of the double track systems. The lack of dormitories for students compelled some of them to rent rooms outside schools for their accommodation. Hence, monitoring and supervision of students by school authorities was woefully ineffective. These students were also exposed to some heatless community neighbours who take advantage of their situation to sexually harass female students. The numerous track vacations further worsen the plight of these students who idle about during such periods.

Furthermore, one of the reasons for the implementation of the free senior school policy, thus, the double system was to bring financial relief to parents. This was, however, found be the reverse as $34 \%$ respondents lamented the system has rather brought untold hardship to parents. With the exception of the textbooks that is being provided the state, the elective courses materials are born by the students. Besides, some parents have to spend lots of money on vacation classes expenses as well as engaging private teachers at home for their wards. In some instances, parents enroll their wards in private schools and pay exorbitant fees for the period they are on holidays. So, parents and guardians arerather spending a lot of money in educating their wards than making savings as the policy intends to achieve.

Additionally, the delay in disbursement of funds to the various schools by the government is yet another challenge of the policy. $10 \%$ headmasters interviewed indicated government inability to release grants timely for the successful operations of these schools. This often compel school heads to resort to borrowing from creditors who also have their own laid down conditionalities at a cost. In some instances where the grant is released, not all but just a percentage is given to manage the situation. Such practices are not novel to government implementing free secondary education in sub-Saharan Africa as they tend to spread the same resource over a relatively large students population in the face of revenue rigidities (Verspoor, 2008). The implication of this, however, is that it has the tendency of compromising quality education.

As a result of the above constrain, the students interviewed lamented that the quality and quantity of food serve as meals is nothing to write home about. Food rationing becomes the order of the day by school management when funds are not disbursed timely and are also inadequate. Reduced and under nourished meals is not something to encourage at this level especially at a time that elimination of malnutrition and the eradication of poverty and hunger has taken a center stage in human development.

Lastly, the study observed that teachers were not motivated enough to put in their best performance. $6 \%$ of the teachers sampled noted that provision in the form of overtime allowance and other incentives have not been catered for by the policy. They lamented that with the increased enrollment numbers, they are compelled to work under pressure preparing lesson notes, organizing exams, making scripts, supervising students and other social activities just to meet the timelines of the double track calendar. Yet not is being done to oil the wheels of customs.

\section{Way Forward with the Free SHS Double Track Policy}

Going forward, the study proposed the following recommendation;

- Policy makers should adopt down-top approach instead of top-down approach in formulating Ghana education service policy should involve headmasters, parents and teachers since they are the implementors and direct beneficiaries of the policy.Top down Policies should not be pushed down to teachers but rather involved them in the decisions making process. Teachers get motivated when they are involved in the decision-making process and ensure its successful implementation in their various schools. The policy goals get affected when stakeholders at the grassroot level are not consulted for their opinions and input.

- Sustainable sources of funding should be established to make the policy viable just as it is in the developed nations.

- Government should endeavor to release grant timely to ensure the smooth operations of the schools. The disbursement resources and logistics should be regular and consistent to improve the quality of education.

- The government should also speed up the expansion of infrastructure to correspond with the increased enrollments. Frantic efforts in this direction will help scrape the double track system which came into being because of since infrastructure deficit.

- The Ministry of Education in collaboration with government should provide appropriate textbooks for both core and elective subjects and relevant teaching and learning materials for effective teaching and learning. 
- Ghana Education Service should reconsider BECE candidate's cut-off point (thresholds) on the computerize school selection and placement system by looking at the passes of the students, the programs chosen by the students and the school selected. The quest to increase enrollment and education for all should not be the reason for lowering the pass mark since this could influence rolling out half-baked graduates.

- For Ghana education policy to yield the desired results, there is the need for serious commitment to political will. Successive governments should not abandon or adopt policies just because they want to fulfill a political or campaign promise.

\section{References}

i. Derbile, E.K. (2003).' Women in Non-farm Enterprise Development and Poverty Reduction in Kasena-Nankane District of Northern Ghana'. Kumasi Nkrumah University of Science and Technology, Department of Planning.

ii. Palys, T.S. (1992), Research Decision; Qualitative and Quantitative Perspectives Toronto: Harcourt and Brace, Canada.

iii. Shepsle, and Kenneth, (1989). 'Studying Institutions: Some Lessons from the Rational ChoiceApproach.'Journal of Theoretical Politics 1:131-147.

iv. Scharpf, and Fritz. (1997). Games Policy Actors Play. Boulder, CO: Westview Press.

v. Sabatier, Paul, and Hank Jenkins-Smith, (1988). 'Special Issue: Policy Change and Policy-Oriented Learning: Exploring an Advocacy Coalition Framework.'Policy Sciences 21:123-272.

vi. Sabatier, Paul, and Hank Jenkins-Smith, (1993). Policy Change and Learning: An Advocacy Coalition Approach. Boulder, CO: Westview Press.

vii. Sabatier, and Paul, (1993). Policy Change and Learning: An Advocacy Coalition Approach. Boulder, CO: Westview Press.

viii. Schlager, and Edella, (1995). 'Policy-Making and Collective Action: Defining Coalitions withinthe Advocacy Coalition Framework.' Policy Sciences 28:243-270.

ix. Ostrom, (1990). Governing the Commons. Cambridge, England: Cambridge University Press.

x. Acedo C. (2009). Inclusive education: Pushing the boundaries. Available from: https://www.researchgate.net/publication/227295798_inclusive_education_pushing.

xi. Ali, N., Jusoff, K., Ali, S., Mokhtar, N. \& Salamat, A. S. A. (2009). The factors influencing students' performance at University Technology MARA Kedah, Malaysia. Management Science and Engineering, 3(4): 81-90.

xii. Creswell, J. W. (2006). Educational research: Planning, conducting, and evaluating quantitative and qualitative research. 3rd Edn., Upper Sadle River, NJ: Pearson Education.

xiii. Creswell, J. W. (2009). Research design: Qualitative, quantitative, and mixed methods approaches. 3rd Edn., London, England: Sage.

xiv. https://www.ghanaweb.com/GhanaHomePage/features/implication. [Accessed February 2019].

xv. Cohen, L., Manion, L. \& Morrison, K. (2008). Research method in education. New York: Routledge.

xvi. Mc William, H. O. A. \& Kwamena-Poh, M.A. (1978). The development of education in Ghana. London: Longman Group Ltd.

xvii. Mensah. D.K.D, (2019).Teachers' Perspective on Implementation of the Double Track Senior High School System in Ghana.International Journal of Emerging Trends in Social Science, ISSN: 2521-3539.Vol. 5, No. 2, pp. 47-56, 2019

xviii. Ministry of Education, (2018). Budget estimates budget estimates of Ministry of Education. Accra: Publishing House.

xix. Partey, A.P. (2018). Implications of a double-track school calendar on SHS.

xx. Sabatier, P. \& Jenkins-Smith, H. (1993). Policy change and learning: An advocacy coalition approach. Boulder: Westview.

xxi. Sabatier, P. A. (1988). An advocacy coalition framework of policy change and the role of policy- oriented learning therein. Policy Sciences, 21(2-3): 129-168.

xxii. Sapru, R.K. (2012). Public Policy: Formulation, implementation and evaluation. New Delhi: Sterling Publishers. Chapters 1,2 and5.

xxiii. A Brief History of Ghana's Educational System, available at www.ghanaembassy.org (accessed, 7th September, 2015).

xxiv. George, Stein Betty (1976). Education in Ghana, Washington, 1976, PP. 29.

xxv. Boahen, A. Adu. (2000) Evolution and Change in the Nineteenth and Twentieth Centuries, Sankofa Educational Publications Ltd.

xxvi. David Williams, 'Sir Gordon Guggisberg and Educational Reform in the Gold Coast, (1919-1927),' Comparative Education Review, Vol. 8, No. 3, Dec, 1964.

xxvii. Moses K. Antwi, (1992) Education Society and Development in Ghana, Unimax Publishers Limited, pp. 23

xxviii. Graham, C.K. (1971). The History of Education in Ghana: From the Earliest Times to the Declaration of Independence, Frank Cass \& Co. Limited.

xxix. Jophus Anamuah Mensah Committee Report, (2007). Meeting the Challenges of Education in the Twenty First Century.

xxx. Awaisu Imurana Braimah.et. al, (2014) 'One State, Two School Systems: The Instability of Ghana’s School System since the Fourth Republic,' Journal of Education and Practice, vol.5, No.9. 
xxxi. Samuel Adu-Gyamfi, Wilhemina Joselyn Donkoh and Anim Adinkrah Addo, (2016) Educationa Reforms in Ghana: Past and Present, Journal of Education and Human Development; published by American Research institute for policy Development. Vol.5.No 3, pp 158-172.

xxxii. Adams, M., \& Anum, J. (2005). Statistical information resources and development planning in Ghana. Information Development, 21(2), 138-144. doi: 10.1177/0266-6669.05.054.50

xxxiii. Adamu-Issah, M., Elden, L., Forson, M., \& Schrofer, T. (2007). Achieving universal primary education in Ghana by 2015. A reality or a dream? UNICEF workingpaper. Retrieved from www.unesco.org/new/fileadmin/.../HQ/ED/gmr2011-referencespdf

xxxiv. Agbenyega, J. (2007). Examining teachers' concerns and attitudes to inclusive education. International Journal of Whole schooling, 3(1), 41-56. Retrieved from

xxxv. http://www.education.wayne.edu/wholeschooling/....Schooling/.../3-1\%20Agbenyegadoc

xxxvi. Akyeampong, K., Djangmah, J., Oduro, A., Seidu, A., \& Hunt, F. (2007). Access tobasic education in Ghana: The evidence and the issues Country analytic report, Consortium for Research on Educational Access, Transitions and Equity (CREATE). Retrieved from http://www.create-rpc.org

xxxvii. Akyeampong, K., \& Furlong, D. (2000). Ghana: A baseline study of the teacher education system. MUSTER Discussion Paper No. 7. Retrieved from http://www.infa.central.sussex.ac.uk

xxxviii. Anamuah-Mensah, J., Ankomah, Y., \& Mankoe, J. (2006). Progress towards attainment of EFA Goals. In Ghana National Commission for UNESCO (Ed.), Overcoming inequality: UNESCO Publications.

xxxix. Bame, K. (1991). Teacher motivation and retention in Ghana. Accra: University Press.

xl. Bridgeman, P., \& Davis, G. (2003). 'What use is a policy cycle? Plenty, if the aim is clear'. Australian Journal of Public Administration., 62(3), 98-102.

xli. Bureau of African Affairs. (2011). Background Note. Ghana. Retrieved from http://www.state.gov

xlii. Bybee, R. (2003). Improving Technology Education: Understanding Reform. The Technology Teacher, 62(8), 22-24.

xliii. Cohen, l., Manion, L., \& Morrison, K. (2007). Research methods in education (6th ed.). Abingdon, Oxon: Routledge.

xliv. Curriculum Research and Development Division. (2007). Subjects and proposed period allocations for the junior high schools in Ghana. Accra: Retrieved from http://www.moess.gov.gh/aboutus.html.

xlv. Davis, G., Wanna, J., Warhurst, J., \& Weller, P. (1993). Public policy in Australia. Sydney: Allen \& Unwin.

xlvi. Everett, S. (2003). The policy cycle: Democratic process or rational paradigm revisited?The Australian Journal of Public Administration, 62(2), 65-70.

xlvii. Fobih, D., Akyeampong, K., \& Koomson, A. (1999). Ghana primary schooldevelopment project. Final evaluation of project performance. Retrieved from http://www.greenstone.org/greenstone3/nzdl...7a...

xlviii. Foster, P. (1965). Education and social change in Ghana. Chicago: University of Chicago Press.

xlix. Fredua-Kwarteng, E. (2008). Compulsory schooling policy in Nunavut: Challenges and suggestions. Leadership and Policy in Schools, 7(4), 428-450. doi:

l. $10.1080 / 15700760802247361$

li. Ghana Education Service. (2004, June). The development of education national report: Ghana. Paper presented at the 47th session of the International Conference on Education, Geneva. http://www.dfid.gov.uk [15/10/2011]

lii. Godwyll, F. (2003). Education at the crossroads: The Ghanaian dilemma and puzzle. Netherlands: Spingerlink.

liii. Hess, F. (1999). A political explanation of policy selection: The case of urban school reform. Policy Studies, 27(3), 459-473. doi: 10.1111/j.1541-0072.1999Ib01980x

liv. Howard, C. (2005). The policy cycle: A model of post-Machiavellian policy making? The Australian Journal of Public Administration, 64(3), 3-13.

lv. Martin, C. (1976). Significant trends in the development of Ghanaian education. Negro Education, 45(1), 46-60.

lvi. Ministry of Education Science and Sports. (2000). Levels of education: Education reform program, 1987. Retrieved from http://www.ghana.edu.gh

lvii. Ministry of Information and National Orientation. (2007). Ghana's education system. Retrieved from http://www.ghana.gov.gh/ghanas_education

lviii. Rodrigue, J., Comtois, C., \& Slack, B. (2009). The policy processes. In J. Rodrigue (Ed.), The Geography of transport systems (2nd ed.). New York.: Routledge.

lix. Rural Health Research Panel. (2007). Bridging rural health research and policy. Dissemination strategies. Retrieved from www.rupri.org/Forms/Health_Panel_Aug07.pdf

lx. Sackey, H. (2008). Private returns to education in Ghana: Implications for investmentsin schooling and migration. Retrieved from http://www.aercafrica.org

lxi. Sutton, R. (1999, August). The policy process: An overview. Paper presented at the Overseas Development Institute: Working paper 118, Stag Place, London, SWIE 5DP.

lxii. Todd, P., \& Wolpin, K. (2006). Ex ante evaluation of social programs. Retrieved from

lxiii. http://anthena.sas.upenn.edu/-petra/papers

lxiv. Tagoe, M. (2011). Lifelong learning and the attainment of the education-related Millenium Development Goals 2 and 3 in Ghana: Is there a critical nexus? International Journal of Lifelong Education, 30(1), 19-35.

lxv. Ghana Education Service. (2004, June). The development of education national report: Ghana. Paper presented at the 47th session of the International Conference on Education, Geneva. http://www.dfid.gov.uk [15/10/2011]

lxvi. Inkoom, A. (2012) implementation of initiative to reform the quality of education in rural Ghanaian Junior High Schools. Retrieved From https://re.ecu.edu.au/theses/485 